\title{
Intrapancreatic Accessory Spleen Misdiagnosed as a Nonsecreting Endocrine Tumor: Case Report and Review of the Literature
}

\author{
Anita Kurmann Jean-Marie Michel Edouard Stauffer \\ Bernhard Egger \\ Department of Surgery, HFR Fribourg - Cantonal Hospital, Fribourg, Switzerland
}

\section{Key Words}

Intrapancreatic accessory spleen $\cdot$ Nonsecreting endocrine tumor

\begin{abstract}
In a large series of nonselected autopsy investigations an accessory spleen was found in $10-30 \%$. The second most common site is the pancreatic tail (17\%). We report a case of intrapancreatic accessory spleen misdiagnosed as a nonsecreting neuroendocrine tumor of the pancreas. Nuclear scintigraphy may provide the definitive diagnosis of an intrapancreatic spleen and therefore prevent patients from unnecessary major surgery.
\end{abstract}

\section{Introduction}

An intrapancreatic accessory spleen may be misdiagnosed as a nonsecreting neuroendocrine tumor of the pancreas. An accurate diagnosis is crucial since such an accessory spleen does not require surgical treatment. We report a case of an intrapancreatic accessory spleen with review of the literature.

\section{Case Report}

A 67-year-old woman in good general conditions with a family history positive for pancreatic cancer underwent a routine health check. Her personal history was completely uneventful without any symptoms present. Physical examination was normal and laboratory tests revealed normal alpha fetoprotein and carcinoembryonic antigen but a slightly elevated tumor marker CA $19-9$ (35 U/ml; normal $<27.0 \mathrm{U} / \mathrm{ml}$ ). Additional laboratory tests such as chromogranin A, neuron-specific enolase, 5-hydroxyindoleacetic acid, pancreatic polypeptide and substance $\mathrm{P}$ were ordered and normal beside a slightly elevated pancreatic polypeptide level ( $437 \mathrm{pg} / \mathrm{ml}$; normal $<210 \mathrm{pg} / \mathrm{ml})$. The patient also 
underwent a CT scan investigation which showed a $18 \times 15 \times 15 \mathrm{~mm}$ nodular lesion in the tail of the pancreas without any contrast enhancement (fig. 1). An additional octreotide scan was normal. Because of the abnormal tumor markers CA 19-9 and pancreatic polypeptide, a neuroendocrine tumor was suspected, although the image appearances were not typical. Due to this potentially malignant lesion the patient underwent a left-sided splenopancreatectomy. Intraoperatively, a dark red but soft tumor was found in the tail of the pancreas and the lesion was also confirmed by intraoperative sonography. Postoperative histopathological examination revealed a completely intrapancreatic accessory spleen without any signs of a tumor (fig. 2 , fig. 3). The patient's postoperative recovery was uneventful.

\section{Discussion}

During the 5th week of gestation the spleen develops in the dorsal mesogastrium from mesenchymal cells that migrate between the leaves of the mesentery and coalesce [1]. An accessory spleen may arise from isolated cells which rest separated from the main body of the spleen. In a large series of nonselected autopsy investigations an accessory spleen was found in $10-30 \%[1,2]$. In 1,000 consecutive patients undergoing contrast-enhanced abdominal CT scan an accessory spleen was present in 16\% [3]. In $80 \%$ the accessory spleen is located at or near the splenic hilum. The second most common site is the pancreatic tail (17\%) [2].

Differential diagnosis of a solid pancreas tumor includes pancreatic adenocarcinoma, pancreatic neuroendocrine tumor, solid and papillary epithelial neoplasms and metastasis. Pancreatic endocrine tumors are rare $(<10 \%)$ and often localized in the head of the pancreas $[4,5]$. Due to secretion of biologically active substances, $15-53 \%$ of these tumors become symptomatic [4], all others remain initially silent. However $50 \%$ of these nonsecreting endocrine tumors are malignant and require surgical resection [6].

In the English language literature only 11 cases of surgical resection of an intrapancreatic accessory spleen have been reported up to now [7]. In most of these cases the intrapancreatic accessory spleen was misdiagnosed as a pancreatic tumor and patients underwent unnecessary surgery. Most intrapancreatic accessory spleens are roundish and have a characteristic homogenous contrast-enhanced appearance on CT scan with well-defined margins. Most often they are small with a diameter of less than $2 \mathrm{~cm}$ [8]. However, definitive diagnosis based on imaging can be difficult because CT scan, MRI and ultrasound images of such intrapancreatic spleens are quite similar to those of hypervascular pancreatic tumors, as islet cell tumors and acinar cell carcinoma [9].

Using contrast-enhanced ultrasound, Ota and Ono [9] demonstrated in the hepatosplenic phase that contrast medium is trapped by hepatic and splenic tissue, which may allow to distinguish an intrapancreatic spleen from other lesions. Somatostatin receptor scintigraphy (octreotide scan) has a high sensitivity in detection of gastrointestinal neuroendocrine tumors (70-95\%) [10]. However, octreotide scan may also give false-positive results. The presence of somatostatin receptors on the surface of lymphocytes within the splenic tissue, which also bind octreotide with a high affinity, may therefore mimic a neuroendocrine tumor $[10,11]$. Heredia et al. [12] diagnosed in three of five patients an intrapancreatic accessory spleen based on the findings of standard gadolinium-enhanced MRI. However, they were not able to exclude other diagnoses with this investigation, including pancreatic neuroendocrine tumors, pancreatic adenocarcinomas, solid and papillary epithelial neoplasms, and metastasis.

The only possibility to differentiate an accessory spleen from a neuroendocrine tumor are nuclear scintigraphic investigations as $99 \mathrm{~m} \mathrm{Tc}$-sulphur colloid or Tc-tagged 


\begin{tabular}{|c|c|c|c|}
\hline $\begin{array}{r}\text { Case Reports in } \\
\text { Gastro=nterclay }\end{array}$ & $\begin{array}{l}\text { Case Rep Gastroenterol 2010;4:210-214 } \\
\text { DOI: 10.1159/000318857 }\end{array}$ & Published online: July 17, 2010 & $\begin{array}{l}\text { | () } 2010 \text { S. Karger AG, Basel } \\
\text { ISSN 1662-0631 } \\
\text { www.karger.com/crg }\end{array}$ \\
\hline
\end{tabular}

heat-damaged red blood cells scintigraphies. These are investigations which are noninvasive, sensitive and specific for detecting splenic tissue [13, 14].

\section{Conclusion}

In asymptomatic homogenous and well-circumscribed tumors in the pancreatic tail an accessory spleen has to be excluded before surgery. Nuclear scintigraphies such as $99 \mathrm{~m}$ Tc-sulphur colloid or Tc-tagged heat-damaged red blood cells scintigraphies should be definitely routinely used in the preoperative evaluation of nonsecreting pancreatic lesions, particularly those which are located in the body and tail of the pancreas. These imaging modalities may provide the definitive diagnosis of an intrapancreatic spleen and therefore prevent patients from undergoing unnecessary major surgery.

Fig. 1. Arterial phase contrast-enhanced CT scan. Intrapancreatic tumor (arrow) without any contrast enhancement.

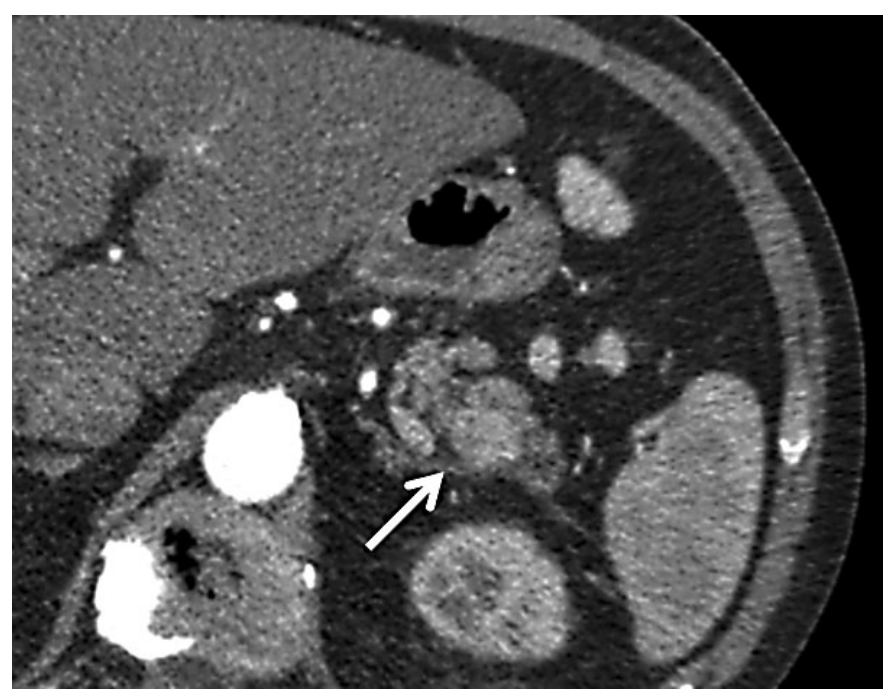




\begin{tabular}{r|l|l|l} 
Case Reports in & $\begin{array}{l}\text { Case Rep Gastroenterol 2010;4:210-214 } \\
\text { D0I: 10.1159/000318857 }\end{array}$ & Published online: July 17, 2010 & $\begin{array}{l}\text { @ 2010 S. Karger AG, Basel } \\
\text { ISSN 1662-0631 } \\
\text { www.karger.com/crg }\end{array}$ \\
\hline
\end{tabular}

Fig. 2. Resected pancreatic tail with the aspect of a well-defined round tumor.

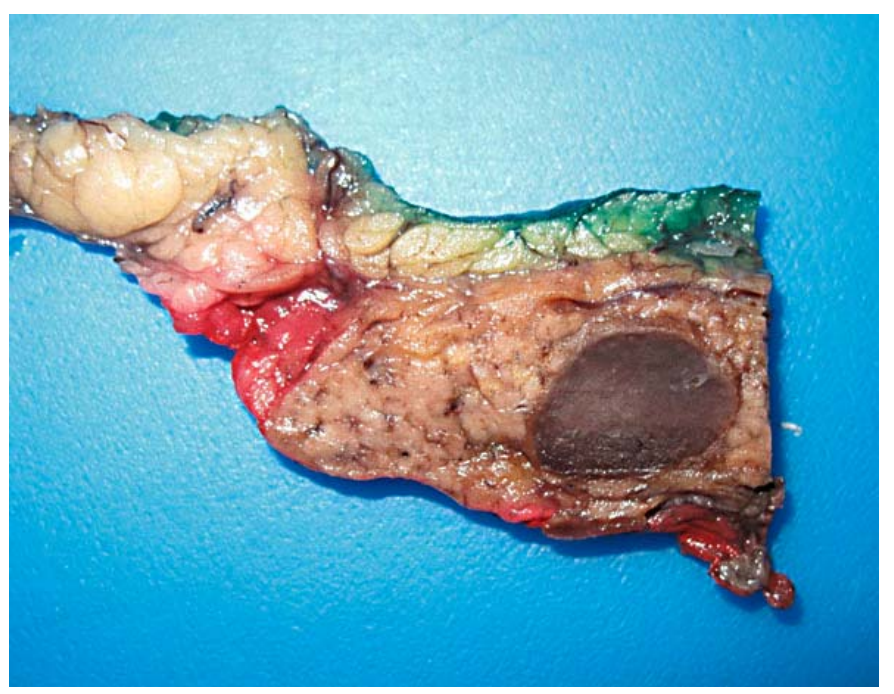

Fig. 3. Histologic staining confirming an intrapancreatic spleen (S) surrounded by pancreatic tissue (P). Hematoxylin-eosin staining.

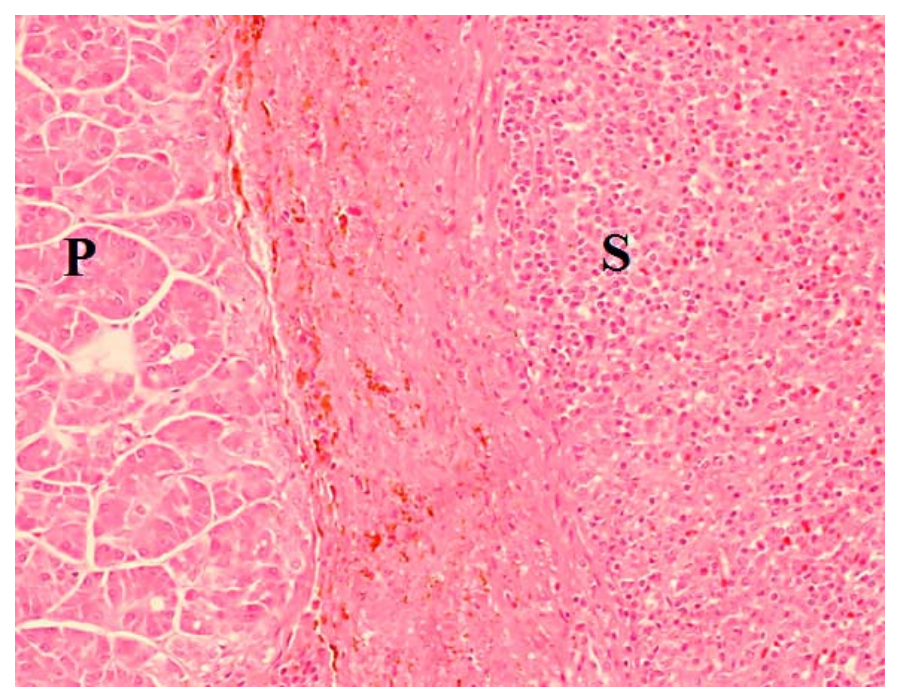




\section{References}

1 Dodds WJ, Taylor AJ, Erickson SJ, Stewart ET, Lawson TL: Radiologic imaging of splenic anomalies. AJR Am J Roentgenol 1990;155:805-810.

-2 Halpert B, Gyorkey F: Lesions observed in accessory spleens of 311 patients. Am J Clin Pathol 1959;32:165-168.

-3 Mortele KJ, Mortele B, Silverman SG: CT features of the accessory spleen. AJR Am J Roentgenol 2004;183:1653-1657.

- 4 Dralle H, Krohn SL, Karges W, Boehm BO, Brauckhoff M, Gimm O: Surgery of resectable nonfunctioning neuroendocrine pancreatic tumors. World J Surg 2004;28:1248-1260.

5 Oberg K, Eriksson B: Endocrine tumours of the pancreas. Best Pract Res Clin Gastroenterol 2005;19:753-781.

-6 Jarufe NP, Coldham C, Orug T, Mayer AD, Mirza DF, Buckels JA, Bramhall SR: Neuroendocrine tumours of the pancreas: predictors of survival after surgical treatment. Dig Surg 2005;22:157-162.

7 Uchiyama S, Chijiiwa K, Hiyoshi M, Ohuchida J, Imamura N, Nagano M, Hidaka H, Yorita K, Akiyama Y, Nishiura M: Intrapancreatic accessory spleen mimicking endocrine tumor of the pancreas: case report and review of the literature. J Gastrointest Surg 2008;12:1471-1473.

-8 Guo W, Han W, Liu J, Jin L, Li JS, Zhang ZT, Wang Y: Intrapancreatic accessory spleen: a case report and review of the literature. World J Gastroenterol 2009; 15:1141-1143.

-9 Ota T, Ono S: Intrapancreatic accessory spleen: diagnosis using contrast enhanced ultrasound. Br J Radiol 2004;77:148-149.

10 Lebtahi R, Cadiot G, Marmuse JP, Vissuzaine C, Petegnief Y, Courillon-Mallet A, Cattan D, Mignon M, Le Guludec D: False-positive somatostatin receptor scintigraphy due to an accessory spleen. J Nucl Med 1997;38:1979-1981.

-11 Meyer-Rochow GY, Gifford AJ, Samra JS, Sywak MS: Intrapancreatic splenunculus. Am J Surg 2007;194:75-76.

12 Heredia V, Altun E, Bilaj F, Ramalho M, Hyslop BW, Semelka RC: Gadoliniumand superparamagnetic-iron-oxide-enhanced MR findings of intrapancreatic accessory spleen in five patients. Magn Reson Imaging 2008;26:1273-1278.

13 Schwartz TL, Sterkel BB, Meyer-Rochow GY, Gifford AJ, Samara JS, Sywak MS, Johnson FE: Accessory spleen masquerading as a pancreatic neoplasm. Am J Surg 2009;197:e61-e63.

14 Sica GT, Reed MF: Case 27: intrapancreatic accessory spleen. Radiology 2000; 217:134-137. 